\title{
Lumen
}

Selected Proceedings from the Canadian Society for Eighteenth-Century Studies

\section{Daniel Defoe and Islam}

\section{Robert Merrett}

Volume 24, 2005

Indigenes and Exoticism

Indigènes et exotisme

URI : https://id.erudit.org/iderudit/1012172ar

DOI : https://doi.org/10.7202/1012172ar

Aller au sommaire du numéro

Éditeur(s)

Canadian Society for Eighteenth-Century Studies / Société canadienne d'étude du dix-huitième siècle

\section{ISSN}

1209-3696 (imprimé)

1927-8284 (numérique)

Découvrir la revue

Citer cet article

Merrett, R. (2005). Daniel Defoe and Islam. Lumen, 24, 19-34.

https://doi.org/10.7202/1012172ar

Copyright (c) Canadian Society for Eighteenth-Century Studies / Sociéte canadienne d'étude du dix-huitième siècle, 2005
Ce document est protégé par la loi sur le droit d'auteur. L'utilisation des services d'Érudit (y compris la reproduction) est assujettie à sa politique d'utilisation que vous pouvez consulter en ligne.

https://apropos.erudit.org/fr/usagers/politique-dutilisation/ 


\title{
2. Daniel Defoe and Islam
}

\begin{abstract}
Boswell: I should wish to go and see some country totally different from what I have been used to; such as Turkey, where religion and every thing else are different.
\end{abstract}

Johnson: Yes, Sir; there are two objects of curiosity, - the Christian world, and the Mahometan world. All the rest may be considered as barbarous. ${ }^{1}$

James Boswell's eagerness to explore religious and cultural difference and Samuel Johnson's conviction that Islam, in comprising a distinctive world-view equivalent to Christianity, is a civilizing power help to clarify why Daniel Defoe, in his earliest work published at age twentythree in 1683, voiced an interest in Turkish affairs and the Mohammedan world, an interest he sustained in a fifty-year-long writing career. Since he habitually explores topical interests from contrary perspectives, this is no less true of his stances towards Islam. Although, on the surface, he seems to be conflicted about Islam because he expresses both repulsion for and attraction to the cultural modes of the Ottoman Empire and is similarly ambivalent about the bond between Islamic religion and politics, his many references to Islam throughout his career do more than substantiate Linda Colley's claim that 'some acquaintance with Islam was a constituent part of polite British culture. ${ }^{2}$ Defoe's references to Islam juxtapose apprehension and admiration of Islamic culture for

1 James Boswell, Life of Johnson, ed. R. W. Chapman (London: Oxford University Press, 1953), 1218.

2 For Defoe's topical and rhetorical modes, see my 'Narrative Contraries as Signs in Defoe's Fiction,' Eighteenth-Century Fiction 1, no. 3 (1989): 171-85. I have consulted Bernard Lewis, What Went Wrong? The Clash Between Islam and Modernity in the Middle East (New York: Oxford University Press, 2002) and The Crisis of Islam: Holy War and Unholy Terror (New York: Modern Library, 2003) for Islam's historical relations with Europe. See Linda Colley, Captives (New York: Pantheon, 2002), 106. 
critical purposes that are relevant to contemporary theories of literary history. ${ }^{3}$ The nexus of fear and imitation of exotic mores that Defoe's references form conveys not only that the British imperialism emergent in his lifetime, was, far from being monolithic, replete with ethical and cultural complexities but also that early modern attitudes to Orientalism were neither fixed nor certain. The very diversity with which Defoe records and explores British attitudes to Islam affords scope for ironical and satirical commentary in his non-fiction and fiction.

At the start of his career, Defoe did not share the hope of Whig friends that the Turks' siege of Vienna would succeed. Besides objecting to Turkish military ruthlessness, to the 'Cruelty and perfidious Dealings of the Turks in their wars,' he refused to tolerate their hostility to Christianity because they had 'rooted out the Name of the Christian religion in above Threescore and Ten Kingdoms. ${ }^{4}$ He preferred that religious strife continue among European Christians than see Turkish incursions overpowering Christianity: he had rather that 'the Popish House of Austria should ruin the Protestants in Hungaria, than the Infidel House of Ottoman should ruin both Protestant and Papist, by over-running Germany. ${ }^{5}$ Fear of Islam displaces fear of Catholicism and enthusiasm for Protestantism. Uppermost in his mind is European military resistance to Islam. In a letter written to Robert Harley twenty years later, he proudly recalls chiding those who had wanted the Turks to capture Vienna so that Protestantism might be established there. He emphasizes that only politicians totally lacking foresight could have believed it 'were Bettre

3 Ania Loomba's digest of Edward Said's Orientalism and its critics in Colonialism / Postcolonialism ([London: Routledge, 1998], 48-54) supports my sense that generalizations about Augustan writing which pretend that individual authors inevitably advance singular ideological positions are misleading.

4 Paula R. Backscheider, in Daniel Defoe: His Life (Baltimore and London: The Johns Hopkins University Press, 1989), claims that Defoe's first publication evidences 'the impetuousness and extremism' that led him to join the Monmouth Rebellion as a soldier (44-45). Backscheider does not consider that Defoe's polemical stance detaches himself from the sectarian thinking he was expected to uphold. If, as David Bayne Horn says, the religious enthusiasm that greeted the relief of Vienna was 'almost unaffected by political calculation' (Great Britain And Europe In The Eighteenth Century [Oxford: Clarendon, 1967], 360), Defoe was not single-minded in his enthusiasm. Since his satire of British culture requires external standards, he equates aspects of Ottoman and Roman imperialism to unsettle British ideology.

5 Daniel Defoe, An Appeal to Honour and Justice in Selected Writings of Daniel Defoe, ed. James T. Boulton (London: B.T. Batsford, 1965. Reprint. Cambridge: Cambridge University Press, 1975), 191. 
for all the Rest of Europe That the Protestants of Hungaria [be] Entyrely Roted Out and Destroyd, Than That the Turks Should Take the Citty of Vienna. ${ }^{\prime 6}$ This anti-Islamic stance is not simply antagonistic; it implies that there cannot be any easy rapprochement between the Holy Roman Empire and Protestant Europe and that proselytism on behalf of Protestantism is no absolute imperative. Defoe's ironically sustained view of the Turks' failed siege of Vienna suggests that, in his long-term goading of friendly Whig dissenters, we may detect an ideological flexibility which defies single-minded accounts of Whig imperialist thinking. ${ }^{7} \mathrm{We}$ may confirm this contrarian aspect of Defoe's Whig ideology by examining his positive views of Turkish militarism before detailing his rhetorical deployment of Islam for divergent satirical ends.

On occasion Defoe not only admires Turkish militarism but also draws from it metaphors which he directs at Christian hypocrisy and lack of moral fortitude. In the first place, he sees Turkish militarism as comparable to that of ancient Rome and contemporary Europe. Far from merely decrying the Ottomans, he grants that their 'martial warlike Princes' have 'enlarg'd their Empire' by perpetually engaging in war so that 'their Soldiery might not lose their Vigour, that their swords might not rust, and that they might not want experienc'd Officers.' In Defoe's mind, the Turks are admirable to the degree that they understand how to maintain a powerful standing army by integrating military policy and military practice. Having once made it their 'Business to over-run the World,' they effectively train up a 'furious bloody Generation. ${ }^{\prime 8}$ Another method they employ is to dismiss failed generals speedily and to justify such dismissals according to the myth that failure is visited on such generals by angry gods. These methods, says Defoe, of

6 Letter 14 [July-August 1704?] in Daniel Defoe, The Letters of Daniel Defoe, ed. G. H. Healey (Oxford: Clarendon, [1955] 1969), 46.

7 Laura Brown, in Ends Of Empire: Women and Ideology in Early Eighteenth-Century English Literature (Ithaca: Cornell University Press, 1993), insists on 'the self-confident, monolithic truth of the Augustans' (2) which, she says, has been matched by critics' concerns with 'political stability, cultural consolidation, canonical authority, and formal complexity' in the period (9). In focussing on the 'radical, protofeminist advocacy of female liberty' in Roxana, she holds that Defoe repudiates his protagonist's feminism in the denouement (17). However, Defoe faults as much as celebrates British imperialism, just as he both satirizes and sympathizes with Roxana throughout the novel.

8 Daniel Defoe, The Complete English Tradesman in Familiar Letters. 2 vols. 2d. ed. (London: Charles Rivington, 1727. Reprint. New York: Augustus M. Kelley, 1969), II, i, 275. Hereafter abbreviated as CET. 
renewing military hierarchy and binding military loyalty to success follow the ruthlessly efficient modes of Grecian, Roman, and Carthaginian armies. ${ }^{9}$ Although, as we shall see, Defoe depreciated Turkish militarism as a model for English commerce in order to promote the pacificism of British trade expansion, that he saw little difference between the warfare of classical Europe and Islam explains why he felt free to extract from Islamic militarism negative images that fortify his attack on the immorality of Christians. Thus, he compares the self-destructiveness of those whose indulgences bring diseases on their bodies to how 'Algerines assault a Ship with Carcases and Stinking Pots. ${ }^{10}$ Likewise, he compares the 'complicated Mischiefs' of partners who marry without loving one another to victims of Moorish piracy who 'look on their Life as a Slave at Algier looks upon his Chains, they fancy themselves as Persons only bought and sold, as Persons committed by Warrant, and made Prisoners for Life' (CJ 172). ${ }^{11}$

If in their consumerist and sexual habits Christians demean and violate themselves to such an extent that Defoe illustrates their abjection by analogies to Islamic military aggression against enemies and slaves, we shall not be surprised that he makes the Turkish empire into a cultural touchstone when reflecting more broadly on his native land. The civilized achievements of the Ottoman empire enter into his geographical, demographic, and economic survey in A Tour through the Whole Island of Great Britain since he willingly concedes British ties to Asia Minor. His patriotic and nationalistic survey admits Turkish orientalism, deriving from it historic and symbolic points of reference. Thus, when he praises the terrace at Windsor Castle built by Elizabeth I, boasting its superiority to all architectural features in France's royal

9 Letter 11 [June 1704?] in Letters, 24.

10 Daniel Defoe, Conjugal Lewdness; or, Matrimonial Whoredom, introd. Maximillian E. Novak (London: T. Warner, 1727. Reprint. Gainesville, Florida: Scholar's Facsimiles \& Reprints, 1967), 394-95. Hereafter abbreviated as CJ. In 'Of Heroic Virtue,' Sir William Temple denies honour to Islamic militarism: the Grand Vizier's lust for gold and refusal to share it with his army explains the Ottomans' defeat before Vienna. To Temple, their empire is built on 'the practices of a subtle man upon the simplicity of a credulous people' (Five Miscellaneous Essays, ed. Samuel Holt Monk [Ann Arbor: University of Michigan Press, 1963], 163-64). Temple's European prejudice led him to claim that the Ottoman empire had been dormant for a century, a claim refuted by Colley (Captives, 65). Defoe exploits ambivalence about this claim.

11 Enslavement by the forces of Islam was familiar to many Britons. Colley estimates that 20,000 were captured as slaves by the Moors in the hundred years between the middle of the seventeenth and eighteenth centuries (Captives, 56). 
palaces, he adds that 'The grand seignior's terrace in the outer court of the Seraglio, next the sea' comes close yet remains inferior, as far as he can tell from his reading. ${ }^{12}$ His allusion to the Ottoman emperor's architecture allows Defoe to heighten his disparagement of France, the true imperial rival.

His account of horse-breeding in Yorkshire in the face of competition from equine imports from Islamic nations expresses national pride more defensively. Even so, the economic protectionism, which this aspect of the agrarian revolution moves him to invoke, necessarily admits a degree of commercial integration between Great Britain and the Ottoman empire. High consumer demand for extravagantly priced horses imported from Islamic nations not only inflates their cost but also devalues horses that are increasingly better bred in Yorkshire. Whereas he grants that Yorkshire breeders do not 'preserve the pedigree of their horses for a succession of ages' as in Arabia and Barbary, he insists they are beginning to 'christen their stallions' and, by so attending to bloodlines, breeding strength and speed into their stallions' offspring so that English horses 'will beat all the world' ( $T$ II, 221). Ironically, his promotion of English horses against favoured exotic Arabian horses rests on the claim that English horse-breeding has improved as a result of military needs. Given his appreciation of the landed interest's resistance to military engagements abroad, it is yet more ironical that Defoe urges landed gentry to acknowledge the advantages of Yorkshire horses: during the late war, horse-breeders produced faster charging horses for soldiers, such horses happening to be highly suitable for hunting. ${ }^{13}$ The London market's high valuation of Arabian horses means that, since Yorkshire horses are unduly cheap, they should be bought by well-to-do patriots.

Whereas, because imported Islamic horses devalue English animals, Defoe wants to restrict their importation, he was not a single-minded

12 Daniel Defoe, A Tour through the Whole Island of Great Britain, introd. G. D. H. Cole and D. C. Browning (London: J. M. Dent, [1928] 1974), I, 303. Hereafter abbreviated as T. Ilse Vickers shows that Defoe models A Tour on Baconian experimentation practised by the Royal Society. Yet, given his concern to promote useful knowledge and to balance natural improvements with submission to nature's powers, he subtly plagiarizes and adapts the works of scientists and antiquarians (see Defoe and the New Sciences [Cambridge: Cambridge University Press, 1996], 151-76).

$13 T$ II, 224. Defoe was familiar with the language and idioms of horse-trading. He knew that the market for horses included a complicated vocabulary of body-parts and diseases which, if customers did not know, they risked being fleeced and deceived (CET I, 31). 
mercantilist as regards trade to the Levant. Far from simply wanting to increase exports and import bullion, he promoted exportation while aware of the social and economic upheavals competition for Turkish markets could create. Attempts to sustain economic growth by increasing the Ottomans' demand for English cloth was impelling towns to specialize, reshaping industries and causing demographic upheaval. The Turkey trade was transforming internal geographical relations since increased competition caused towns to seek for niche markets. Small towns, such as Burstall in Yorkshire, concentrated on producing and dyeing broad cloths since the Turkish market for kersey and shalloon had been captured by Halifax, Huddersfield, and Bradford. But the latter, in their turn, could no longer compete with the counties of Wiltshire, Gloucestershire, Somerset, and Devon in producing kersies and druggets for the Turkey trade (T II, 203).

Defoe's awareness of the Turkey trade's effect on regional competition in England extends to what is called 'internal colonialism. ${ }^{14}$ Measuring and regulating that trade was vital to the nation's economic well-being because of the harm that the misrepresentations of commercial propaganda might cause: false estimates of imports and exports endangered livelihoods and upset the domestic circulation of trade. His belief that London was the trading hub of Great Britain around which Scotland, Ireland, and Wales should revolve is clear when he attacks inflated claims for the amount of Scottish trade to the Orient. He rejects these claims as 'scandalous partiality': he emphasizes that, if the Scots do export to China and the East Indies, to Turkey and the Levant, they do so only in 'the service of English merchants' (T II, 279).${ }^{15}$ Trade with the Islamic world led Defoe to uphold economic protectionism against imperial rivals both internally in Scotland and Ireland and externally in France. While he claimed to be amazed by the human imagination's capacity to accept the paradoxes of trade, he himself heightened imaginative and symbolic paradoxes about trade to defend English national-

14 See Janet Sorenson, 'Internal Colonialism and the British Novel,' Eighteenth-Century Fiction 15 (2002): 53-58.

15 Niall Ferguson, Empire: The Rise and Demise of the British World Order and the Lessons for Global Power (New York: Basic Books, 2003), shows that, while Scotland had less than ten percent of Great Britain's population in 1750, the East India Company was 'at the very least half-Scottish' (45). For Defoe's disgust with Scotland's failure to improve nature with scientific and commercial energy, see Vickers, Defoe and the New Sciences (174-75). 
ism. ${ }^{16}$ This explains how he celebrates The Royal Exchange founded by Sir Thomas Gresham. Defoe reads the founder's statue with its bale of silk facing the Turkey Walk as both a token of Gresham's work for the Levant Company and a symbol of the mythical continuity of the English throne $(T \mathrm{I}, 351){ }^{17}$

This paradoxically symbolic importance of the Turkey trade extends to domestic and familial life in the regions around London as well as to cloth-manufacturing towns throughout the British isles. About the town of Eltham near Greenwich, which had long been populated by rich citizens, Defoe records that they had sent off so many young men to train as Turkey merchants that young women there, with much reduced courtship prospects, threatened to abandon the town. ${ }^{18}$ By contrast, family and social life had been stabilized at nearby Lusum, where Sir John Lethulier, a distinguished Turkey merchant, not only had lived to a great age but in doing so had helped several of his sons to establish noble seats and considerable estates in the district (TI, 100). An ambivalent example of the influence of the Turkey trade is found in the case of Sir John Morden, a Turkey merchant who lived nearby at Black-Heath. Despite the 'misfortunes of the times,' the trading losses incurred by Islamic depredations - losses that curtailed his philanthropy - Morden is praised for having built a fine hospital to shelter 'forty decay'd merchants,' affording them the dignity of dying like gentlemen. To Defoe, this hospital symbolizes the noblest 'single piece of charity' offered to London in many years $(T I, 96)$.

If he promotes the pacific, constructive qualities of British trade to attack Turkey's hierarchical militarism for resisting internal trade and destroying external commerce, Defoe does not maintain this stance when feeling obliged to charge British merchants with narrow self-interest. He certainly focuses on devising methods for expanding the Turkey trade that counteract Islamic maritime aggression: he proposes restoring trade to North Africa by rooting out the Moors of Tunis, Tripoli, Algier,

16 Colin Nicholson, Writing and the Rise of Finance: Capital Satires of the Early Eighteenth Century (Cambridge: Cambridge University Press, 1994), 46.

17 A major aspect of Gresham's significance to Defoe was that he was one of the founders of the Bank of England. On the commercial, imperial, and cultural significance of The Royal Exchange, see Joseph Addison's panegyric of May 19, 1711 in The Spectator, Vol. I (London: Dent, 1945), 212-15.

18 That Roxana sends a wife to her son, a trader to Turkey, (see below page 32) shows she is aware of the plight of brides-to-be caused by bachelors engaged in imperial commerce. 
and Sallee, whom he likens to the Romans and Vandals in their plundering of the region's trading cities. ${ }^{19}$ Since commerce is a universal good, he holds that 'the Followers of Mahomet are, wherever they come, like the Romans, the Destroyers both of Commerce and Cultivation.' Being 'a rapacious, cruel, violent, and tyrannical People, void of all Industry or Application, neglecting all Culture and Improvement,' the Turks of North Africa are 'Thieves and Robbers.' Having been displaced from Valencia, Granada, and Andalusia, they turned piratical, stealing ships from all 'the Christian Nations of Europe' and raiding inland Mediterranean settlements to make slaves of the country people as well as of captured sailors. Further, he proposes outflanking the Ottoman empire by expanding trade to East Africa, not by military aggression, but by establishing fortified settlements at the mouths of two rivers in southern Ethiopia outside the reach of Turkish control that was limited to the northern Red Sea. But at this point in A Plan of the English Commerce he turns against Britain's merchant community, faulting the East India Company for not having already opened up this market: he charges the company with wrongly insisting on its exclusive charter rights at the expense of pioneering trade routes. Islam alone is not responsible for problems in the Turkey trade; English merchants, far from adopting positive attitudes or accurately assessing market potential, are remiss. They avoid evidence which indicates Britain's scope to outperform France. Defoe claims that English cloth, according to ambassadors' reports, is appreciated in oriental courts: 'the Grand Seignior, Lord of the whole Turkish Empire, has his Robe of English Cloth, and the Sophy of Persia, amidst all his Persian and Indian Silks, wears his long Gown of Crimson Broad Cloth, and esteems it, as it really is, the noblest Dress in the World.' Claiming to know what Turkish consumers want, Defoe holds that French cloth, light-weight, cheap, and highly coloured though it may be, wears worse than English cloth. The latter, heavier by the bale, is generally bought, though at a dearer price, by Turkish and Armenian merchants, the chief dealers in woolen goods. Turkish or Persian gentlemen, the Aga or Bassa, know that English wool is firm, smooth, and solid to the last whereas French wool, which wears rough, light, and spongy, soon turns to rags. Nor have English merchants done a good enough job in importing raw materials. If the Turkey trade has declined, this is not because of a lack of markets for English cloth. Rather, silk from Turkey

19 Daniel Defoe, A Plan of the English Commerce (London: C. Rivington, 1728. Reprint. Oxford: Basil Blackwell, 1927), 234-39. Hereafter abbreviated as PEC. 
has inexplicably so declined in quality that British weavers have turned instead to Piedmont and Bengal silks: Turkey merchants have not carefully selected silk of a quality good enough to import as a producer good (PEC 258-59, 136, 132-33, 208-09).

Defoe's critical ambivalence about Islamic and British economic practices is not occasional but habitual, as evident in his satirical contrariness with regard to English merchants in The Complete English Tradesman. ${ }^{20}$ Addressing fears for the Turkey trade given that French was underselling English cloth at Aleppo and Smyrna, he urges English merchants to act more energetically in marketing their superior products: they need not passively wait to promote their trade until the French leave Constantinople sometime in the future (CET I, i, 123). English merchants had better grasp the structural economic differences between the advanced manufacture of linen and the primitive one of silk. When merchants from Georgia and the Caspian Sea take their silk to Aleppo and Scanderoon to exchange it for British merchandise, 'our Turkey merchants' import the silk as a producer good but do so without employing credit or refined accounting methods (CET I, Supplement 32-33). ${ }^{21}$ The silk trade by contrast to the linen trade is 'a mean remote thing' because merchants accompany their cargoes, simply vesting their returns in the goods of local markets. By this distinction, Defoe does not mean to disparage Islamic commodities simply; he praises Barbary wool and Turkey's Caramania-wool, regretting that such small amounts are available for importation. His point is clarified by comments on British success in importing cloth to Spain: Spain has to import British wool because the lingering effect of the Moorish occupation is a domestic slowness to grasp industrial improvement, a slowness which has enabled British manufacture to produce superior 'Spanish-Cloths' (CET II, ii, 52).

Although Defoe felt confident about the division of labour, the employment of the poor, and the function of capital and credit within the British economy, his sense of its structure and of the nature of its growth

20 While James Thompson posits an inverse relation between images of exchange in PEC and CET (Models of Value: Eighteenth-Century Political Economy and the Novel [Durham: Duke University Press, 1996], 126), my rhetorical focus on the uses of Islam in the two works emphasizes their ideological continuity founded in imperial rivalry with France.

21 Nicholson brilliantly explicates Defoe's contrary sense of credit: it is omnipresent, godlike, immaterial, and imaginary (Writing and the Rise of Finance: Capital Satires of the Early Eighteenth Century, 186-87). 
was critical, as seen when he contrasts the cities of London and Constantinople, finding a model for reform in the latter. The size of London overly depends on the importation of luxury goods from around the globe to cater to gluttony and to prompt cravings: 'our Navigation is chiefly employ'd upon the exorbitances of Life.' The proliferation of commerce in London entails the unregulated propagation of vice, whereas in Constantinople the Turks exchange only the 'more necessary things of Life.' Their 'treats are Coffee, Sherbet, and messes of Rice, dress'd their own way, a little Flesh and but very little.' Their clothes are not gay or ornate except those of the Bassas, Sultans, and persons of rank. Since their fashions rarely change, their clothes are not costly. Also 'their Buildings and Furniture, Gardens, Equipages' lack ostentation, giving employment to none of the artificers who abound in London. Were the London trades to imitate Turkish ones, its population would be much smaller than Constantinople's. That city lacks the malt, distilling, and wine trades, the drinking establishments that employ thousands in the city and countryside, and the trades in personal and domestic fashion, such as wig- and coach-makers. The Turks neither wear wigs nor keep coaches. Defoe agrees with Lady Mary Wortley Montagu that the Turks are far less subject to luxury and snobbery than the English. ${ }^{22} \mathrm{He}$ claims that their mosques do not separate the high and low; the Bassa kneels with the Janizary, their prayers not a matter of status and fashion. Without a colonial empire, a huge mercantile marine, and a complex of fashion industries, Constantinople is city of one million people. Were London to model itself on that city, two-thirds of its population would have to take up a rural subsistence. By contrasting the economies of the two cities, Defoe does more than chasten tradesmen for promoting trade and vice. He urges the merchant community to regulate itself morally, for he fears the threatened establishment of sumptuary laws, far from reforming consumer vices, would harm trade and employment. ${ }^{23}$

22 See 'Letters during Mr. Wortley's Embassy to Constantinople' (1716-1718) in Letters From the Right Honourable Lady Mary Wortley Montagu 1709-1762, ed. R. Brimley Johnson (London: Dent, 1906), 56-202.

23 CET II, ii, 110-20, 129-44. Defoe holds that English tradesmen are 'a growing race of gentlemen,' their opulence symbolizing the size and intricacy of Britain's economy and empire. The nation's wealth does not derive from military conquest and occupation of foreign lands. The loss of such territories, civil conflicts, and political instability are its precedents. Peaceable trade underlies commercial growth. Discoveries of unknown lands, settlements on uninhabited islands, and colonies on the uncultivated continent of America explain the size of the home economy. Apart from the transplantation of negroes and the displacement of treacherous natives, the 
Far from generalizing about or rationalizing Turkish luxury in ways that the protagonist of Roxana does, Defoe grants that Islamic regulations are structurally as well as morally effective. This is further evident in Conjugal Lewdness in which he shows that, because Islamic law treats marriage as a legal contract rather than a religious sacrament, it offers a conceptual model of sexual reform to England. To Defoe, Turkish society treats wives decently in a legal system which gravely punishes the sexual abuse of women. While British women, if grossly injured, cannot do themselves justice because modesty prevents them voicing details in court, a Turkish woman, injured by 'the Liberties of the Marriage-Bed,' may be redressed by having her husband summoned before the Grand Vizier to answer her complaint. To justify her charge, she need say nothing, nor even unveil her face, until she takes her oath: then, after unveiling, she removes a slipper and holds it up to the Grand Vizier 'the wrong Side upward.' By this symbolic action, she 'swears upon the Alchoran that her Husband offers unnatural Violences to her, and that she cannot live with him upon that Account.' She secures a divorce unless he clears himself or gives security that he will not repeat his offence. Defoe also registers how Mohammedan law shields pregnant women from submitting to intercourse: 'in the Language of Mahometan Modesty,' a wife suffers 'an unnatural Violence' if so injured. Should this happen, she performs a similar action: she holds up sticks to tell the court the number of her husbands' wives. In this matter, Turkish law conforms to the law of nature. ${ }^{24}$ Defoe defends 'the Modesty of Mahometan Nations' in abstaining from intercourse with pregnant wives because polygamy as a tenet of Mahomet's law is based not on sexual necessity but on patriarchal custom. Were polygamy forbidden, Moslems would abstain, he insists, from such 'Pollution and Impurity' because they regard this sexual license as bestiality $(C J, 297-304)$. Urging Christian husbands not to commit rape under cover of marriage, Defoe warns that

colonies have been peopled by transplanted felons. Full domestic employment, population growth, and the fact that the English poor do not need to go and be mercenaries in foreign armies all bear witness to the dynamism of the English economy (CET I, 313-16).

24 There is little evidence for the claim of Virginia Ogden Birdsall that Defoe associates 'the pagan Turks with irrationality and lack of government' (Defoe's Perpetual Seekers: A Study of the Major Fiction [Lewisburg: Bucknell University Press, 1985], 159). In CJ, natural law upholds Islamic sexual practice. Maximillian E. Novak confirms Defoe's view of Turkish rationality (Realism, Myth, and History in Defoe's Fiction [Lincoln: University of Nebraska Press, 1983], 116). 
wives may 'turn the Slipper up against them'; he wishes that 'our fruitful Inventions' had 'added some Signals, some Figures' in the Turkish manner to expose nauseous crimes modestly (CJ, 337).

In showing how symbolic conduct in Islamic jurisprudence might inspire the establishment of emblematic codes in British society to spare the sensibilities of abused women and to protect authors and readers from charges of obscenity, Defoe does not assume that modes of decency may be simply transferred from one culture to another. While he wishes to satirize the moral laxity of British society, his awareness that mores are culture-specific leads him to turn his irony upon orientalism too. $\mathrm{He}$ points out that the eastern method of punishing adulterous women by making them go naked in public is 'a Breach of the very Modesty which it was intended to punish' $(C J, 386)$. In this vein, he establishes what Roxana so easily ignores: sexual modesty may not be based on 'the practice of other Nations.' Going naked, or next-to-naked, may be customary in hot countries such as Italy, Turkey, and Barbary, but is scandalous in England where Christians 'are to cleave so far to the Custom of the Place, as to do all Things that are of good Report. ${ }^{25}$

The last of his major fictions published in 1724, Roxana features a protagonist who, in betraying English customs and Christian values, is crushed by ironies because she appropriates and abuses Turkish modes to dramatize herself for material and libertine reasons. ${ }^{26}$ That she is christened Roxana as she postures in luxurious Turkish clothes that barely hide her fascination with aristocratic French modes reveals her abuse of Christianity, Islam, and cultural history. ${ }^{27}$ Besides transgressing moral and natural law, her luxury and sensuality exploit culture-specific truths. ${ }^{28}$ Her abuse of orientalism and Christianity involves thoughtless

CJ 357; cf. Philippians 3: 8.

26 Daniel Defoe, Roxana: The Fortunate Mistress, ed. Jane Jack (London: Oxford University Press, 1964). All references are to this edition.

27 Sandra Sherman holds that Roxana evades history since Defoe aims to maintain generic indeterminacy (Finance And Fictionality In The Early Eighteenth Century: Accounting for Defoe [Cambridge: Cambridge University Press, 1996], 157-58). Tracing fictionality in all Defoe's works, Sherman declines to differentiate between truth and fiction; to classify his fictions as novels, in her view, depreciates his imaginative creativity.

28 Maximillian Novak, in Realism, Myth, and History in Defoe's Fiction, calls Roxana 'a novel of moral decay' (100). Roxana's abuse of primitivism leads him to see her as a 'curious combination of mythic synchronic time and the particular serial chronology of history' (116). 
rationalizations which always emphasize her self-victimization. Her construction as a negative exemplum and Defoe's relentless irony arise from his experimental wish, as in Conjugal Lewdness, to treat shocking subject-matter inoffensively. Everything Roxana does, including the unfinished writing of her autobiography, leads to 'many dark Reflections.' When she goes on the Grand Tour with the prince whom she idolizes and to whom she is a snare in the devil's hand, the inverse relation of her material survival and spiritual degradation is set. When at Naples he buys her 'a little Female Turkish Slave' captured by a Maltese man-ofwar, the relation becomes more complex via cross-cultural references. The slave teaches her Moorish songs and dances as well as the Turkish language (102-03). Since the vessel seized by the man-of-war between Constantinople and Alexandria had well-dressed ladies on board, Roxana acquires fine clothes that her slave teaches her to wear. Thus, she displays herself in 'the Habit of a Turkish Princess' at a masquerade she holds for the English Court in her grand London apartment. Dramatizing herself in this exotic, if meretriciously worn, costume, she claims to be a Mahommedan who disclaims English dancing. Agreeing to dance, she calls for music 'a la Moresque,' provoking one masked courtier to say that she has a Christian face and 'that so much Beauty cou'd not be Mahometan.' After she dances three French dances with this mask, she performs the figure of a famous Parisian master, a figure by which she entertained her prince. The company, deceived into thinking it a Turkish figure, then christens her Roxana. Ironically, her name stems from a concurrence of courtly prejudice and stupidity. She may enjoy being the talk of the town but is sickened by the decadence of her masquerade. Similarly, her pride in being close to royalty makes her know nobody, not even herself (173-77). The second masquerade which leads to a three-year retreat with the king educes ironies about her Mahommedan pretensions. While dressing, she is visited by a noble Persian family. Fearing to be outdone by its ladies who are dressed in the style of virgin ladies from Georgia and Armenia, she derides their Persian modes because, if their dancing is novel and pleasing, 'there was something wild and Bizarre in it, because they really acted to the Life the barbarous Country whence they came' (179). Her scorn of the genuine Persian virgins rests on prejudice for French luxury: she is more pleasing because she has 'the French Behaviour under the Mahometan Dress' (180) ${ }^{29}$ Her 
moral sense of indecency is incipient, not developed: when dancing privately for the king, she merely feels her dress is 'somewhat too thin' because 'unlac' $d$ and open-breasted, as if I had been in my Shift' (181).

Defoe's ironies about Roxana's appropriation of Turkish modes gather force because she compulsively displays and conceals herself while evading sustained personal and cultural reflections. Upon attaining financial independence, she would make amends for her life by providing for her children. But ironies she sets in motion oppose maternal instinct to moral self-destruction. Through the agency of Amy, her servant-confidante, she educates her son so that he may be 'put to a Turkey-merchant' (192). Financing his apprenticeship with an Italian merchant at Messina, she has him established in an English house trading to the East Indies, hoping he will gain forty or fifty thousand pounds. Yet, because he will not readily marry a woman she sends out to him, Roxana cuts him off from further investments and a legacy on the implausible grounds that he abuses her (264).

The recoil of ironies upon Roxana caused unknowingly by her daughter, Susan, are more tragic. The nearer Susan comes to discovering that Roxana may be her mother, the more Roxana must push her daughter away, the more she has to deny her, until, goaded by unselfconscious hints from Roxana, Amy murders the displaced, identity-seeking daughter. Having served for two-years as a cook-maid in Roxana's house during the period of her fashionable masquerades, Susan comes close to uncovering her relation to Roxana on account of the Turkish costume. Although she takes up lodgings with a Quaker to present a modest face to the world, Roxana not only hungers for titles and fame but relives her past by entertaining her husband, the Dutch merchant, with French songs and her Turkish dress which she wears in private. By this time, she realizes that it is not 'a decent Dress in this Country'; it is 'one degree off, from appearing in one's Shift.' But, because she adorns the dress with her husband's picture in the eastern mode, she leads him to ask her to don it often. She also tempts the Quaker to change her habit for such a dress. Susan makes a surprising visit to Roxana when she is wearing an Italian morning-gown which, plainly exposing her body, reminds Susan of the Turkish dress. Susan's reactions to Roxana's habit are transparent on this and later occasions both to her Dutch husband and to her Quaker confidante. Trapped by her compulsive indulgence in foreign modes which she dislikes, Roxana must listen to Susan as the latter slowly, agonizingly recovers Roxana's masquerades while in ignorance revering her mother as an angel. Ironically, Susan's narrative recovery is so exact that it matches Roxana's desire for fame. But the faithful narration causes Roxana to regard her daughter merely as 'this young Slut,' a pejoration which forces upon Roxana her own non-entity and dark reflections 
whose depth escapes her (288). Roxana's attempts to divert and discredit Susan's narrative recovery only strengthen the symbolic nexus of the Turkish dress. All Roxana can do is to remain silent so as not to provoke a fuller narrative. Her autobiography ironically dramatizes authorial inhumanity. By depreciating Susan's image of her mother, Roxana aggravates her own narrative self-destruction, thus imitating the moral theme that her mortifications are endless and fruitless. When the Quaker, in misplaced friendliness, decries Susan's narrative by asserting that Roxana has a dress superior to the one Susan has described, the Quaker exquisitely but, of course, unknowingly tortures Roxana and pushes her closer to thwarting Susan's quest in the most sinful of ways (290).

Defoe's familiarity with the Turkey trade, knowledge of the Ottoman empire, and curiosity about Mohammedanism led him to explore the cultural interface between Islamic and Christian values in non-fiction and fiction. ${ }^{30}$ His attitudes towards economic progress, consumerism, marital conduct, and private and public morality were shaped by a dialectical sense of Islam. As the cross-cultural references in Roxana attest, Turkish modes helped him address images of social decadence and personal moral grossness with precise, sustained, and profoundly reflexive ironies. The contrarian thinking enlivened by his imaginative sympathy for Islam is evident in his other novels. When Robinson Crusoe is captured at sea by Barbary corsairs and made a slave in Morocco, he is treated well. ${ }^{31}$ Again, in A Journal of the Plague Year, H. F.'s brother warns him against imitating the 'profess'd predestinating Notions' of Moslems who die by the thousands because they go 'unconcern'd into infected Places.' This warning at first changes the Saddler's mind about remaining in London. But he finally resists the warning, his resistance justified since he becomes an accurate reporter of the plague and a keen projector of public policy in the face of urban disaster. Less positively, the citizens of London not only display 'a kind of a Turkish

30 For further evidence of Defoe's topical familiarity with Islam, see William Lee, Daniel Defoe: His Life and Recently Discovered Writings, 3 vols. (London: Hotten, 1869. Reprint. New York Burt Franklyn, 1969): the 'Balm of Mecca' from a tree blessed by the 'great Prophet Mahomet' (II, 392): in December 1721, English captives released by the King of Fez and Morocco marching in 'Moorish Habits' through London to St. Paul's (II, 461); the possible Treaty of Partition between Russia and Turkey for the territories of the Sophy of Persia (III, 210-11); and courtly oriental bombast (III, 221-24). In the 1721 ransom, the British government handed over 1200 barrels of gun-powder and 13,500 gun-locks, thus confirming Colley's view of the interdependence of European and Islamic states (Captives, 68).

31 Colley, Captives 1, 58. 
Predestinarianism' during the plague but also, when it seems to be flagging, many are 'more obstinate' than Mohameddans because they behave with 'audacious Boldness' before death, heeding no admonition about the continuing operation of the 'Contagion.' ${ }^{32}$ The point here is that Defoe denies categorical status to notions of cultural superiority; Londoners in crisis ironically behave according to their worst projections of Mohammedans. If Defoe did not desist from believing in Islamic barbarity and cruelty, he confronted his beliefs with an open-mindedness that enabled him to develop a genuinely critical and reformist perspective on English culture and the self-deceiving and illusory trust in its superiority. If he did recall how the Earl of Shaftesbury condemned the 'Moorish fancy' of English readers for cultivating corruption by favouring barbaric over classic tales and by ignoring the Mahomeddan clergy's discouragement of 'all true learning, science, and the polite arts,' including comparative literature, on behalf of the perfect inimitability of their scriptures, Defoe found it more important to invent satirical and narrative procedures that would make this fancy recoil upon itself in the service of a broad-minded and tolerant sense of individual reform and cultural integrity. ${ }^{33}$ Defoe's rhetorical deployment of Islam confirms that he resists his own and his society's prejudices and tests received ideas by contrary viewpoints. For him, imperialism is both a good and bad thing, and imagining Islam, if possibly personally alienating, is just as likely to be ethically helpful and socially constructive.

ROBERT MERRETT

University of Alberta

32 Daniel Defoe, A Journal of the Plague Year, ed. Louis Landa (London: Oxford University Press, 1969), 11-12, 193, 230.

33 Anthony Ashley Cooper, Characteristics Of Men, Manners, Opinions, Times, ed. John M. Robertson (Indianapolis: Bobbs-Merrill, 1964), I, 221-223 \& II, 301. 